\title{
Blue toe syndrome
}

\author{
Síndrome do dedo azul
}

\author{
Paulo Eduardo 0 cke Reis*
}

\begin{abstract}
The authors report the case of a man with blue toe syndrome, who developed bilateral foot ischemia and underwent successful repair of an abdominal aortic aneurysm and associated renal artery stenosis. Blue toe syndrome is characterized by tissue ischemia secondary to embolization of cholesterol crystals or atherothrombotic debris. $\mathrm{M}$ icroembolization most often occurs in el derly men who undergo an invasive vascular procedure or have an aneurysm.
\end{abstract}

Key words: blue toe syndrome, atherosclerosis, aortic aneurysm, renal artery stenosis.

Blue toe syndrome is one of the frequent manifestations of tissueischemia. C yanosis of the digits may have several etiologies ranging from trauma to connective tissue disease. $\mathrm{H}$ owever, the most common cause of bluetoesyndromeisthe atheroembolic disease or aneurysm.

\section{C ase report}

A 55-year-old man was admitted to the hospital with a four-month history of bilateral lower extremity pain and blue discoloration of toes. The bilateral foot pain had worsened for the past 1-2 months. The pain was relieved by rest, severely limited physical activity and walking. $\mathrm{H}$ e had smoked since the age of 20. $\mathrm{He}$

\footnotetext{
* MD. Chief of Vascular Surgery, Hospital Antonio Pedro/Universidade Federal Fluminense, Rio de Janeiro, RJ. Vascular Surgeon, Hospital Pró-Cardíaco, RJ.

Article submitted on September 19, 2005, accepted on November 11 2005.
}

J Vasc Br 2005;4(4):391-3.

Copyright (C) 2005 by Sociedade Brasileira de Angiologia e Cirurgia Vascular.

\section{Resumo}

O s autores relatam o caso de síndrome do dedo azul em um homem que apresentou um quadro de isquemia bilateral dos pés e foi submetido ao reparo bem sucedido de um aneurisma da aorta abdominal e de estenose da artéria renal associada. A síndrome do dedo azul é caracterizada pela isquemia tecidual, secundária à embolização de cristais de colesterol ou aterotrombose. A microembolização ocorre mais freqüentemente em homens idosos que têm um aneurisma ou são submetidos a um procedimento vascular invasivo.

Palavras-chave: síndrome do dedo azul, aterosclerose, aneurisma de aorta, estenose de artéria renal.

had a history of arterial hypertension, angina, renal insufficiency, a 4-cm abdominal aortic aneurysm (AAA) and bladder neoplasm treated 10 years before. $M$ edicationsat thetime of admission were: atorvastatin, lisinopril, hydrochlorothiazideand acetyl-salicylic acid. Upon examination, the abdomen was soft, with a pulsatile massin theepigastric region. $\mathrm{H}$ ehad cold feet, with a decrease of tactile sensation. Femoral, popliteal, DP and PT pulses were palpable bilaterally. All toes were cyanotic and cool and the right big toe was ulcerated. A C T scan of theabdomen and pelvisshowed an infrarenal AAA measuring $4 \mathrm{~cm}$ in diameter. A renal artery duplex showed right and left renal arteriesstenosis at their origins, with peak systolic velocities of $262 \mathrm{~cm} /$ $\mathrm{sec}$ and $449 \mathrm{~cm} / \mathrm{sec}$, respectively. The patient was admitted to the hospital for surgical treatment. U nder general anesthesia, a retroperitoneal approach was performed to expose the abdominal aorta and the left renal artery. The aorta and renal arteries were dissected and proximal and distal control obtained. A longitudinal aortic arteriotomy wasmadeand an organized thrombus was removed from theaorta. The procedureperformed 
was an aorto-aortic bypass graft with a side-arm left renal artery $D$ acron-PT FE bypass graft (Figure 1). The patient wasmaintained in an intensivecareenvironment for thefirst 2 days after thesurgery. T he creatininelevel was $2.9 \mathrm{mg} / \mathrm{dl}$ before the operation and came down to $2 \mathrm{mg} / \mathrm{dl}$ in thepostoperativeperiod (Figure2). Theurea nitrogen dropped from $49 \mathrm{~g} / \mathrm{dl}$ before the operation to $28 \mathrm{~g} / \mathrm{dl}$ afterwards (Figure 3). The urine output immediately after the operation was greater than $200 \mathrm{ml} / \mathrm{h}$ and the renal function gradually improved over the course of a few weeks. The histological examination of the aneurysm contents showed only thrombus and calcified debris.

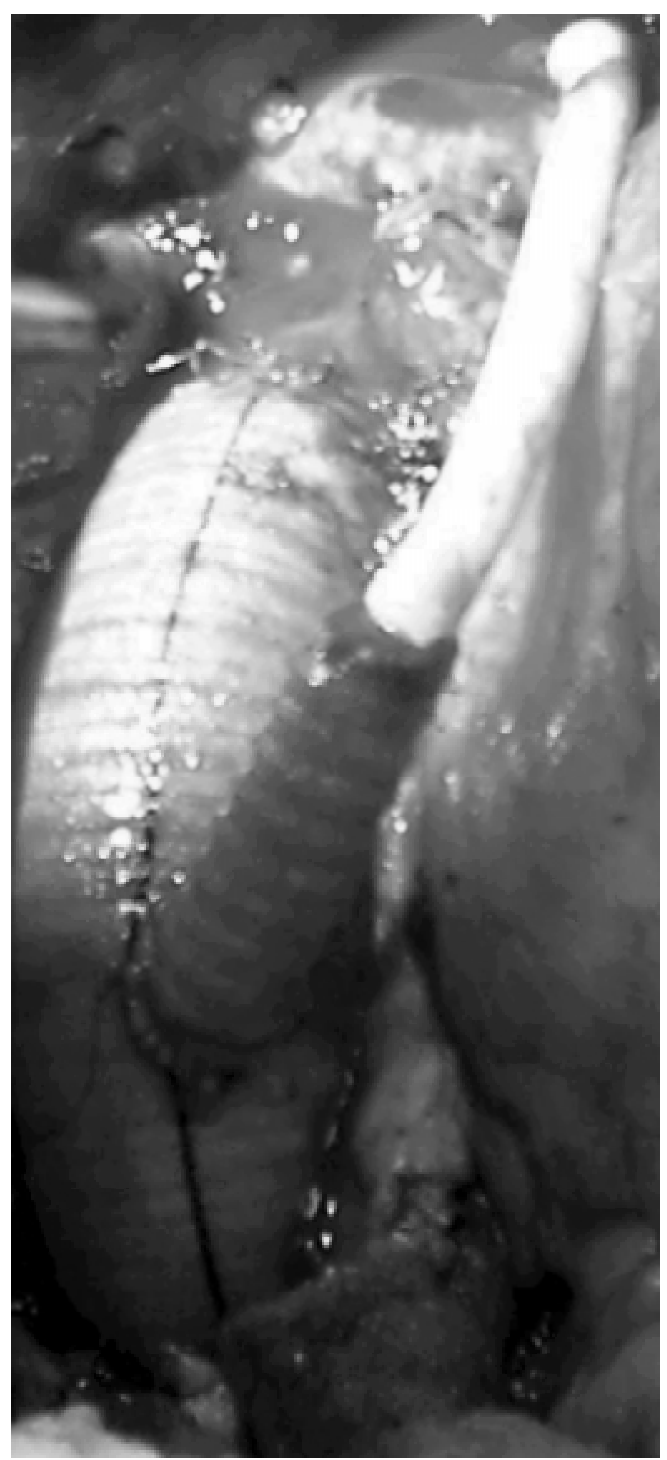

Figure 1 - Aorto-aortic and aortorenal bypass

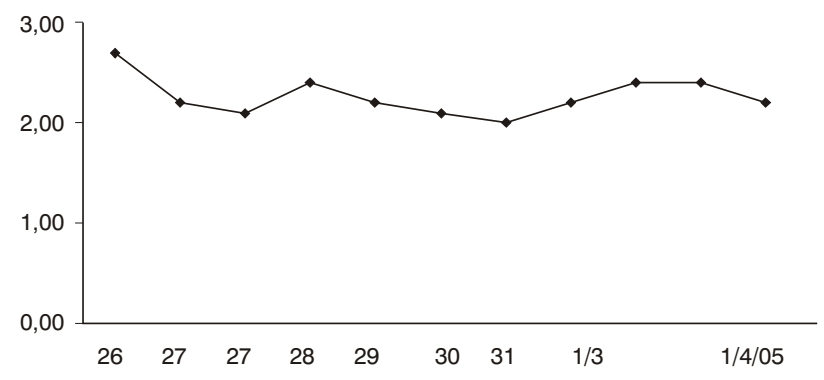

T able 1 - C reatinine decrease after the aorto-renal bypass in $12 / 27 / 04$

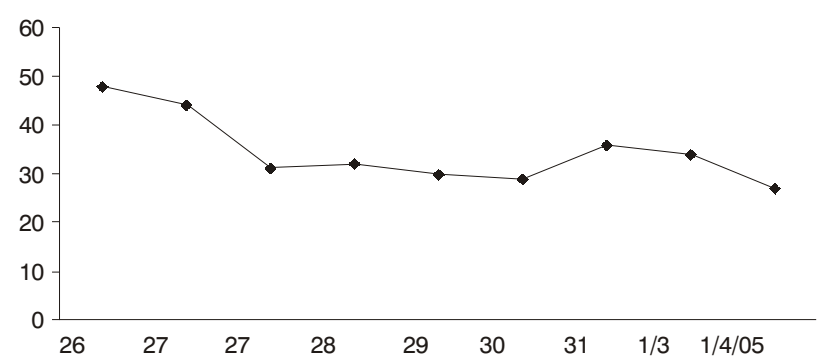

T able 2 - U rea decrease after the surgery

\section{D iscussion}

Thetherapeutic goal for bluetoesyndromeconsists of surgical or percutaneous elimination of the source of embolism. M icroembolization most often appears in elderly men who have undergone an angiographic procedure or vascular surgery or even anticoagulant or thrombolytic treatment.1,2 The differential diagnosis includesRaynaud's(especially secondary) phenomenon. In blue toe syndrome skin lesions are usually restricted to the occluded artery. Clinical presentation can range from a cyanotic toe or livedo reticularis to a diffuse multiorgan systemic disease that can mimic other systemic illnesses. The kidney is the organ that is most frequently affected (in approximately $50 \%$ of cases). In the systemic form prognosis is poor, with a mortality rate of about $70 \%$.

The association with renal vascular hypertension and heart diseaseincreasesthechances of complications after the surgery.

The syndrome of cholesterol embolism in this case needs an urgent approach due to the distal ischemic 
pain. The occlusion of small distal vessels was caused secondary to embolization of the cholesterol crystal from the aneurismal wall. In addition, our patient is young and had a small AAA associated to renal stenosis.

Thedecision regarding thetype of intervention was not easy. The overall benefit of the endovascular treatment of AAA is well established. ${ }^{3-5}$ There was also the option to perform the renal angioplasty before the aneurysm treatment. Alternatively, we could have first done the endovascular approach to the renal artery. $\mathrm{H}$ owever, we decided to do the conventional approach for both illnesses at thesametime. Thereasonswere: age (55 years old), the short neck of the proximal aorta in the CT scan, and to avoid contrast and the renal stenosis. The authors believe that up to this moment there are no benefits to do the renal artery stenting to improverenal function in a young patient who is going to suffer an open procedure anyway. Renal artery stenting isassociated with restenosisrates (approximately $20 \%$ ) and clinical failure rates of at least the same degree. Also, theintermediateterm resultsaresimilar to open repair. 6

In this case we decided to treat the abdominal aneurysm by open technique. Then our decision was to do the retroperitoneal access and fix both the aneurysm and the left renal stenoses. The incision was placed in line with the ribs to avoid injury to the intercostal nerves. The purpose of the operation is to place a prosthetic graft inside the aneurysm and anastomose the graft at its ends to relatively normal arteries. An aorto-aortic bypass was performed, as well as an aortorenal bypass. At thistime, during theperformance of theoperation and surgical technique, technical notes should be made to identify the left renal artery. In addition, the left kidney is retracted anteromedially. It is our routine to feel the pulse of the renal artery. To improve the flow, the prosthesis should be parallel to the aorta as shown in Figure 1. For us it is a better way to perform the renal anastomosis. Relief of the pain in thedistal bilateral lower limb wasimmediately observed. The clinical manifestations of the blue toe syndrome and laboratorial examinations stabilized. The distal lesions need amputation or debridement after delimitation of thenecrosis. M edical treatment ismostly symptomatic: rest, warm condition, appropriate dressing, hydration, and organ support when necessary, particularly to ensurerenal function. T reatment of pain that is usually disproportionate to the extension of tissue lesion is of utmost importance. Because these patients usually have advanced atherosclerotic disease, secondary prevention with elimination of risk factors of atherosclerosisismandatory. Antiplatelet drugsrepresent one of thebasic treatment options of bluetoesyndrome. In thefuturelargerandomized studieswill beneeded to help predict embolization and thus decide on the proper medical therapy.

\section{References}

1. Applebaum RM , K ronzon I. Evaluation and management of cholesterol embolisation and the blue toe syndrome. Curr 0 pin Cardiol. 1996;11:533-42.

2. Caldwell BD, M arrochello VS. M icroembolization from atheroembolic disease or aneurysm. A case study. J Am Podiatry M ed Assoc. 1996;86:249-52.

3. G reenhalgh RM . C omparison of endovascular aneurism repair with open repair in patients with abdominal aortic aneurysm (EV AR T rial 1), 30-day operativemortality results: randomized controlled trial. Lancet. 2004;364:843-8.

4. Lederle FA, Wilson SE. Immediate repair compared with surveillance of small abdominal aortic aneurisms. N Engl J M ed. 2002;346:1437-44.

5. Prinssen $M$, V erhoeven EL, Buth J, et al. A randomized trial comparing conventional and endovascular repai $r$ of abdominal aortic aneurysms. N Engl J M ed. 2004;351:1607-18.

6. Burket M W, Cooper CJ, Kennedy DJ, et al. Renal artery angioplasty and stent placement: predictors of a favorable outcome. Am H eart J. 2000;139:64-71.

Correspondence:

Paulo Eduardo 0 cke Reis

Visconde de Pirajá 414/515, I panema

CEP 22410-002 - Rio de Janeiro, RJ

Phone: (21) 2287.5327

E-mail: pauloocke@openlink.com.br 